\title{
Vascular Endothelial Growth Factor (VEGF): An Important Marker of Cure Progression in Schistosomiasis Mansoni Disease
}

\author{
MANAL A. MOUSTAFA, M.D.*; RANIA M. SARHAN, M.D.*; ABEER A. ABDEL-RAHMAN, M.D.*; \\ HEBA N.A.H. ABDEL MENAEM, M.B.B.Ch.*; SAMIA W. ABDEL SAYED, M.D.** and \\ SHIMAA A. ELGOHARY, M.D.*** \\ The Department of Medical Parasitology, Faculty of Medicine, Ain Shams University*; The Department of Medical Parasitology, \\ Theodor Bilharz Research Institute** and The Department of Surgical Pathology, Faculty of Medicine, Ain Shams University***
}

\begin{abstract}
Background: Schistosomiasis is a major health problem infecting about 7.2 million in Egypt. Praziquantel (PZQ) is the only drug effective against Schistosoma mansoni infection without effective available alternatives. VEGF was used to assess the associated schistosomal inflammatory and hepatic histopathological changes.

Aim of Study: The aim of this work is to evaluate the expression of VEGF in hepatocytes and sinusoids of experimental infected mice with Schistosomiasis mansoni comparative to treated group with PZQ.

Material and Methods: Swiss albino mice housed at the Animal House at Theodor Bilharz Research Institute (TBRI), Giza, Egypt were divided into three major categories: Group I (positive control); Group II (negative control); Group III (Infected mice treated with PZQ). They were infected by $(60 \pm 10)$ S. mansoni cercariae. VEGF was measured.

Results: VEGF expression was reduced in hepatocytes and sinusoids in treated group compared with positive control group with non expression in negative control group.

Conclusions: VEGF is an important marker in reflection of infection and progression of treatment. It is a good marker of cure.
\end{abstract}

Key Words: Vascular endothelial growth factor (VEGF) Schistosomiasis mansoni disease.

\section{Introduction}

SCHISTOSOMIASIS is a parasitic disease caused by trematodes of genus Schistosoma that inhabit the circulatory system of their hosts [1]. It infects more than 260 million people and causes 200,000 deaths per year [2]. Schistosoma mansoni is one of the most important species [3].

Correspondence to: Dr. Heba N.A.H. Abdel Menaem, E-Mail: dr.heba92@yahoo.com
Schistosomiasis is a major public health problem in rural Egypt [4], infecting about 7.2 million [5]. It ranks second to malaria in the tropics and subtropics. Africa is the most affected, in addition to 42 countries endemic for the infection. The disability-adjusted life years (DALYs) lost due to schistosomiasis was about 1.7 million [6]. It is a debilitating disease affecting populations with low socio-economic status and limited access to clean water and adequate sanitation [7].

VEGF has been used to assess the associated schistosomal inflammatory and hepatic histopathological changes. It increases hepatic stellate cells (HSCs) activation, proliferation and collagen production. The activated HSCs play role in fibrotic pathogenesis. This plays an important role in chronic schistosomiasis [8].

So, the aim of this study is to evaluate the expression of VEGF in hepatocytes and sinusoids of experimental infected mice with Schistosomiasis mansoni comparative to PZQ treated group.

\section{Material and Methods}

The study was done at the Parasitology Laboratory and Animal House at TBRI, Giza Governorate, Egypt and according to the Schistosome $\mathrm{Bi}$ ology Supply Center (SBSC) of Theodore Bilharz institution in accordance with those of Higher Ministry of Education. Following a randomized sample, Swiss albino mice around six to eight wks old, weighing 18 to 22 grams were housed at the Animal House at TBRI, Giza, Egypt, at the time from September 2018 to August 2019. 
Twenty mice were infected by tail immersion technique by $(60 \pm 10) \mathrm{S}$. mansoni cercariae. Mice were divided into three major categories: Group I (positive control): Ten infected untreated mice; Group II (negative control): Ten healthy uninfected, untreated mice; Group III: Ten infected mice which were treated seven weeks post infection with PZQ given orally in a dose of $200 \mathrm{mg} / \mathrm{kg} /$ day body weight for five consecutive days) [9]. Mice were sacrificed 9 weeks post infection and the results were assessed by immunohistochemical analysis through examining the sites of VEGF expression in hepatocytes and sinusoids. For immunohistochemical staining, sections of 4-5 ickness were cut on poly-LLysine coated slides and left for 30 minutes at $60^{\circ} \mathrm{C}$ in the oven to allow good adherence of the tissues to the slides. VEGF labeling was performed on (Dako-EnVision FLEX) autostainer using DAB as chromogen and hematoxylin as counter-stain. The interpretation of immunoreactivity was carried out by analyzing the number of positively stained cells (in hepatocytes, endothelial cell lining of the blood vessels and sinusoids). The highest expression recorded within 10 successive fields ( $\mathrm{x} 400$ ) was counted per section/animal in a semiquantitative way. The final value represented the mean of 100 readings per group. $0 \%$ was given to unstained sections [10]

\section{Statistical analysis:}

Recorded data were analyzed using the statistical package for social sciences, version 20.0 (SPSS Inc., Chicago, Illinois, USA). Quantitative

Table (1): Comparison between group I and treated group according to hepatocytes of VEGF IHC at immunohistochemical results.

\begin{tabular}{lcccc}
\hline \multirow{2}{*}{ Group } & \multicolumn{2}{c}{ VEGF IHC } & t-test & $p$-value \\
\cline { 2 - 3 } & Hepatocytes & Change\% & & \\
\hline Group I & $73.5 \pm 5.4$ & - & & \\
Group III & $37.8 \pm 5.2$ & $-48.60 \%$ & 10.648 & $<0.001^{* *}$ \\
\hline
\end{tabular}

Using: Independent Sample $t$-test.

${ }^{* *} p$-value $<0.001 \mathrm{HS}$. data were expressed as mean \pm standard deviation (SD). Qualitative data were expressed as frequency and percentage. Independent-samples ( $t$-test) of significance was used. The confidence interval was set to $95 \%$ and the margin of error accepted was set to $5 \%$. So, the $p$-value was considered significant as the following: $p$-value $\leq 0.05$ was considered significant. $p$-value $\leq 0.001$ was considered as highly significant. $p$-value $>0.05$ was considered insignificant.

\section{Results}

Examination of immunostained slides of group II (negative control group) revealed negative VEGF immunostaining (Fig. 1). Examination of immunostained slides of group I (positive control group) revealed positive VEGF expression in hepatocytes and sinusoids about $73.5 \pm 5.4$ and $62.4 \pm 5.9$, respectively.

The expression of VEGF was reduced in both hepatocytes and sinusoids in the treated group when compared with positive control group (infected untreated group). (Tables 1,2 \& Figs. 1,2,3).

This table shows statistically significant difference between group I and Group III according to hepatocytes of VEGF IHC at immunohistochemical results.

This table shows statistically significant difference between groups according to sinusoids of VEGF IHC at immunohistochemical results.

Table (2): Comparison between group I and treated group according to sinusoids of VEGF IHC at immunohistochemical results.

\begin{tabular}{llccc}
\hline \multirow{2}{*}{ Group } & \multicolumn{2}{c}{ VEGF IHC } & t-test & $p$-value \\
\cline { 2 - 3 } & Siusoids & Change\% & & \\
\hline Group I & $62.4 \pm 5.9$ & - & & \\
Group III & $26.5 \pm 5.4$ & $-57.50 \%$ & 10.037 & $<0.001^{* *}$ \\
\hline
\end{tabular}

Using: Independent Sample $t$-test.

*** $p$-value $<0.001 \mathrm{HS}$ 


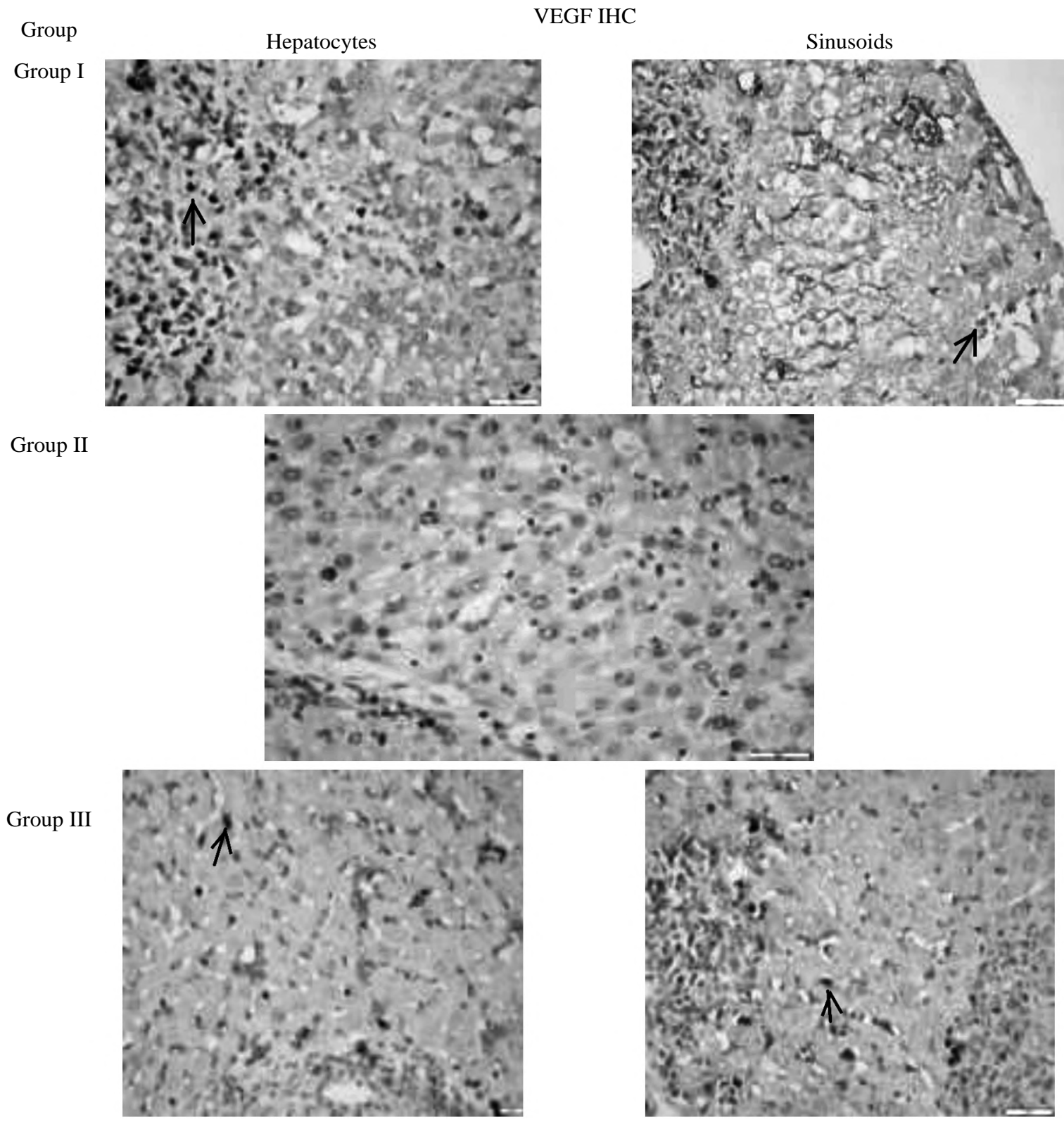

Fig. (1): Immunohistochemical expression of VEGF in control groups and treated group (IHC x400).

Group I: Showing strong positively stained hepatocytes, sinusoids with anti-VEGF antibody.

Group II: Control healthy mice group with negative expression.

Group III: Showing moderately positively stained hepatocytes, sinusoids with anti-VEGF antibody.

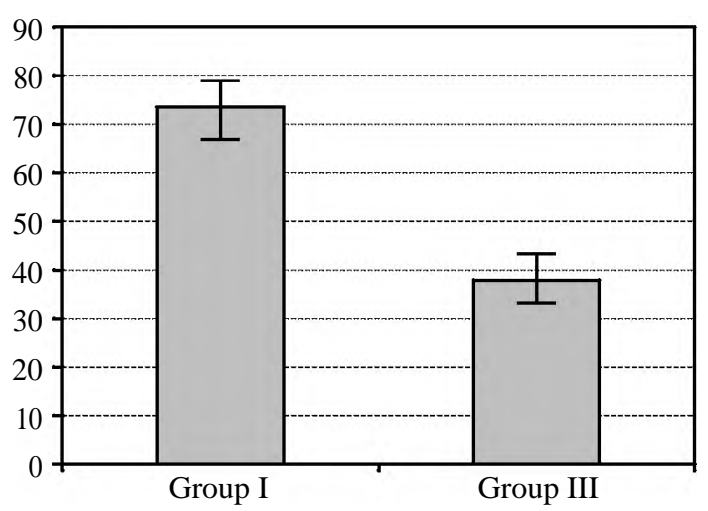

Fig. (2): Comparison between group I and treated group according to hepatocytes of VEGF IHC at immunohistochemical results.

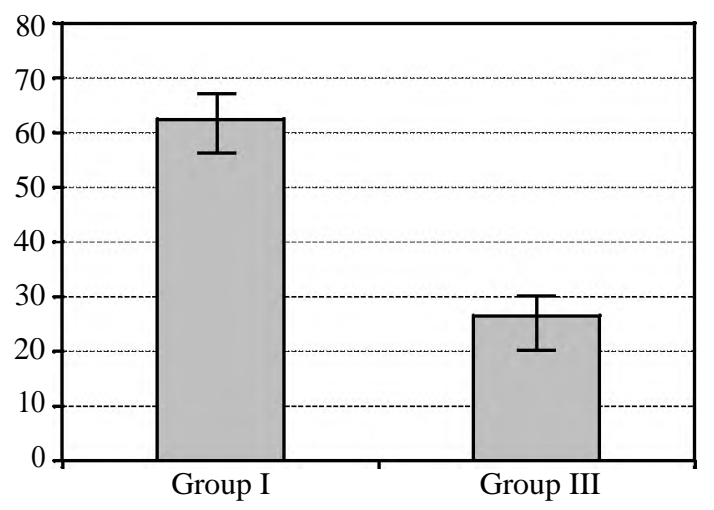

Fig. (3): Comparison between group I and treated group according to sinusoids of VEGF IHC at immunohistochemical results. 


\section{Discussion}

Schistosomiasis remains one of the most common parasitic diseases worldwide. It is associated with a high morbidity and mortality in a large scale in developing countries in tropical and subtropical regions of Africa. Estimates indicate that 779 million people are at high risk of infection and $85 \%$ of them are in Africa. Approximately 207 million individuals in 74 countries are infected with schistosomiasis and 120 million of these people developed the disease [11]. Schistosomiasis is the major public health problem in rural Egypt, with almost six million Egyptians are infected. Lack of knowledge about the disease, poor sanitation and a lack of effective health policies encourage the dissemination of schistosomiasis in endemic countries [12]. Schistosomiasis causes disabling systemic morbidities such as anaemia, malnutrition and impaired childhood development, as a result of the effect of continued inflammation on normal growth, iron metabolism, physical fitness and cognitive function [13]. Serious complications may occur especially if neglected such as portal hypertension, pulmonary hypertension and cor pulmonale [14].

PZQ is the drug of choice for schistosomiasis. It is effective against all Schistosoma species. Common side-effects of PZQ include abdominal pain, headache, dizziness and transient passage of blood in stool. High-burden infections correlate with high risk of side-effects, which peak about 2-4h after drug intake [15]

The present study was done to evaluate the expression of VEGF in hepatocytes and sinusoids of experimental infected mice with Schistosomiasis mansoni comparative to PZQ treated group.

For serving this study, Swiss albino mice were divided into three groups (control groups and experimental group treated with PZQ). Mice were experimentally infected with $\mathrm{S}$. mansoni cercariae $(60 \pm 10$ cercariae) by tail immersion technique. The results was assessed by immunohistochemical procedure [16].

Our results revealed a reduction in VEGF expression in hepatocytes and sinusoids in treated group compared with positive control group. In agreement with the recorded observation, some authors also showed that decreased expression of VEGF in mice treated with PZQ [10]. VEGF stimulates HSCs leading to its activation, proliferation and collagen production. The activated HSCs has an important role in fibrotic pathogenesis. VEGF increases several pro-fibrotic and immune cytokine genes in HSCs, including integrin, fibronectin, interferon- $\gamma$, IL- 6 and IL-10 playing an important role in chronic schistosomiasis [8].

The present study highlighted the impact of VEGF on Schistosomiasis mansoni disease progression. More studies should be performed to demonstrate the impact of VEGF on Schistosomiasis mansoni disease progression under the effect of medications other than PZQ and to clarify its role in disease progression.

\section{Conclusion:}

VEGF plays an important role in chronic schistosomiasis. It is used to assess the associated schistosomal, inflammatory, hepatic histopathological changes. Further studies are needed to clarify the role of VEGF in Schistosomiasis mansoni disease diagnosis.

\section{References}

1- CHITSUlO L., ENGELS D., MONTRESSOR A. and SAVIOLI L.: The global status of schistosomiasis and its control. Acta. Trop., 77: 41-51, 2000.

2- WHO: Weekly Epidemiological Record, Geneva, Switzerland: World Health Organization., 90 (5): 25-32, 2015.

3- CROMPTON D.W.T.: How much human helminthiasis is there in the world? J. Parasitol., 85: 397-403, 1999.

4- WU GEORGE Y. and MOHAB H. HALIM: "Schistosomiasis: Progress and problems." World journal of gastroenterology, Vol., 6 (1): 12-19, 2000.

5- HOTEZ P.J., SAVIOLI L. and FENWICK A.: Neglected tropical diseases of the Middle East and North Africa: review of their prevalence, distribution and opportunities of control. PLoS. Negl. Trop. Dis., 6 (2): e1475, 2012.

6- INOBAYA M.T., OLVEDA R.M., CHAU T.N., OLVEDA D.U. and ROSS A.G.: Prevention and control of schistosomiasis: A current perspective. Res. Rep. Trop. Med., (5): 65-75, 2014.

7- TCHUENTE L.T., ROLLINSON D., STOTHARD J.R and MOLYNEUX D.: Moving from control to elimination of schistosomiasis in sub-Saharan Africa: Time to change and adapt strategies. Infect. Dis. Poverty, 6: 42, 2017.

8- LUO J., LIANG Y., KONG F., QIU J., LIU X., CHEN A., LUXON B.A., WU H.W. and WANG Y.: Vascular endothelial growth factor promotes the activation of hepatic stellate cells in chronic schistosomiasis. Immunol. Cell Biol., 95 (4): 399-407, 2017.

9- DUVALL R.H. and DE WITT W.B.: Technique for recovering adult schistosomes from laboratory animals. The American Journal of Tropical Medicine and Hygiene., 16: 438-486, 1967.

10- BOTROS S.S., HAMMAM O., MAHMOUD M. and BERQUIST R.: Praziquantel efficacy in mice infected with PZQ non-susceptible S.mansoni isolate treated with artemether: parasitological, biochemical and immunohistochemical assessment. APMIS, 118: 692-702, 2010. 
11- HAJISSA K., MUHAJIR A.M.A., ESHAG H.A., ALFADEL A., NAHID E., DAHAB R., ALI S.M., MOHAMMED M., GAAFAR M. and MOHAMED Z.: Prevalence of schistosomiasis and associated risk factors among school children in Um-Asher Area, Khartoum, Sudan. BMC Res. Notes., 11: 779-783, 2018.

12-LEIPER R.T.: Report on the results of the bilharzia mission in Egypt. Transmission. J.R. Arm. Medical Corps., 25: 1$55,1915$.

13- BUSTINDUY A.L., THOMAS C.L. and FIUTEM J.J.: Measuring fitness of Kenyan children with polyparasitic infections using the 20-meter shuttle run test as a morbidity metric. PLoS Negl. Trop. Dis., 5: e1213, 2011.

14- EL BAZ T. and ESMAT G.: Hepatic and intestinal schistosomiasis: Review. J. Adv. Res., 4: 445-452, 2013.

15- COLLEY D.G., BUSTINDUY A.L., SECOR W.E. and KING C.H.: Human schistosomiasis: Lancet, 383 (9936): 2253-2264, 2014

16- HSU S.M. and RAINE L.: Protein A, Avidin and biotin in immunohistochemistry. J. Histochem. Cytochem., 29: 1349-1353, 1981.

\title{
عامل النمو البطانى الوعائى علامة هامة للشفاء

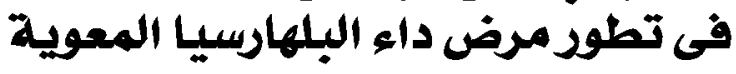

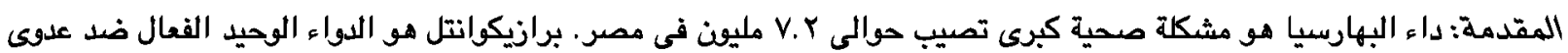

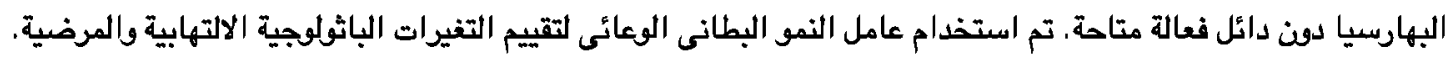 \\ هدف الدراسـة: الهدف من هذا العمل هو تقيّم التعبير عن عامل النمو البطانى الوعائى فى خلايا الكبب والجيوب من الفئران المصابة \\ التجريبية مع داء البهارسيا المعوية مقارتة بالمجموعة المعالجة بالبرازيكوانتل.

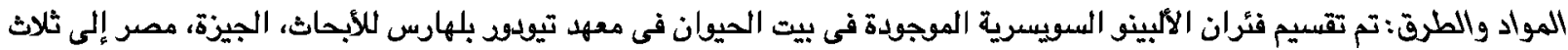 \\ فئات رئيسية: المجموعة الأولى (تحكم إيجابى)، المجموعة الثانية (تحكم سلبى)، المجموعة الثالثة (تم علاج الفئران المصابة بيرازيكوانتل).

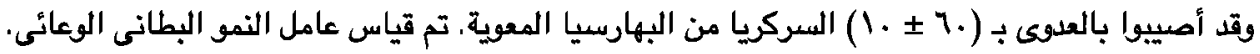 \\ النتائج: تم تقليل تعبير عامل النمو البطانى الوعائى فى الخلايا الكبدية والجيوب فى المجموعة المعالجة مقارنة بالمجموعة الضابطة الإيجابية \\ مع علم التعبير في مجموعة التحكم العيلية.
}

الاستتاجات: عامل النمو البطانى الوعائى هو علامة مهمة فى انعكاس العدوى وتطود العلاج إنها علامة جيدة للثشاء. 